\title{
Economic Contribution to Local Livelihoods and Households Dependency on Dry Land Forest Products in Hammer District, Southeastern Ethiopia
}

\author{
Dagm Fikir, ${ }^{1}$ Wubalem Tadesse, ${ }^{2}$ and Abdella Gure ${ }^{3}$ \\ ${ }^{1}$ University of Gondar, P.O. Box 196, Gondar, Ethiopia \\ ${ }^{2}$ Ethiopian Environment and Forest Research Institute, P.O. Box 24536, 1000 Addis Ababa, Ethiopia \\ ${ }^{3}$ Hawassa University Wondo Genet College of Forestry and Natural Resources, P.O. Box 128, Shashemene, Ethiopia \\ Correspondence should be addressed to Dagm Fikir; dagtfsm@gmail.com
}

Received 18 March 2016; Accepted 31 August 2016

Academic Editor: Piermaria Corona

Copyright (C) 2016 Dagm Fikir et al. This is an open access article distributed under the Creative Commons Attribution License, which permits unrestricted use, distribution, and reproduction in any medium, provided the original work is properly cited.

\begin{abstract}
The study was conducted in Hammer district, Southern Ethiopia, to provide empirical evidence on economic contribution to local livelihoods and households dependency on dry forest products. One agropastoral and two pastoral kebeles were purposively selected, and data was collected through household survey, group discussions, market assessments, and field observation. A total of 164 households, selected based on a random sampling procedure, were interviewed using structured questionnaire. The study found that income from forest products contributes $21.4 \%$ of the total annual household income. The major dry forest products include honey, fuel wood, gum and resin, and crafts and construction materials, contributing $49 \%, 39 \%, 6 \%$, and $6 \%$ of the forest income, respectively. Households of the pastoral site earned more forest income and were relatively more dependent on forest products income than those in the agropastoral study site. Significant variation was also found among income groups: households with higher total annual income obtain more forest income than those with lower income, but they are relatively less dependent on forest products than the lower counterpart. Besides, various socioeconomic and contextual factors were found to influence forest income and dependency. The findings of the study provide valuable information up on which important implications for dry land forest development and management strategies can be drawn.
\end{abstract}

\section{Introduction}

Dry forests play an important role in the livelihoods of approximately one billion people worldwide [1]. In Africa, where $60 \%$ of rural dwellers are poor [2], dry forests represent an important resource base for livelihoods and economic development $[3,4]$. About 320 million people in the continent depend on dry forest resources to meet many of their basic needs [5]. In Sub-Saharan Africa, where poverty and underdevelopment, in terms of infrastructure, government services, markets, and jobs, are characteristics features for most of its parts, about a quarter of a billion people live in or around dry forests [6] and depend on these resources for several products such as building materials, food, cropland, fuel wood, and nonwood products.
Over the past years, the recognition of the widespread reliance of rural people on forest products and the povertyforest use relationships have spawned a growing scientific interest in demonstrating the economic dependence on forest products and understanding its determinants [7-10] The most important argument behind such scientific studies is that empirically based knowledge on people-forests interactions is an important tool in devising alternative strategies for livelihood security, poverty reduction, and dry forest conservation $[11,12]$. Moreover, knowledge about the significance of environmental income is also important to the environmental conservation debate and the tradeoffs and synergies that exist between use and protection.

Economic valuation studies undertaken in different dry forest and woodland countries showed forest related income 
contributions ranging from $6 \%$ to $45 \%$ [9, 11, 13-18]. Studies do also suggest that such contribution, or extent of people's dependency, varies substantially across households due to different factors like wealth status, education, livestock and land holdings, awareness levels, age, gender, household sizes, access to forests and markets, and nonfarm activities [13, 1921].

Of widely discussed factors in forest dependency literature is that of the relationship between wealth and forest products extraction. While some studies reported that poorer households extracted more forest products and are more dependent on forest products than wealthier one [8, 22], others found that households with higher total annual income extracted more forest products than those with lower income, but they are relatively less dependent on forest products than the lower counterpart $[15,23,24]$. This implies that forest-wealth relationship may vary from place to place, and it suggests that there is still a need to increase our understanding in different contexts and geographical areas.

It has also been suggested that the role of forest products may vary with the type of the traditional source of livelihood: due to the reason that farmers, agro/semipastoral, sedentary pastoral, and pastoralist differ in their social and cultural backgrounds, spatial provenance, and their history of close association with nature, their different resource use patterns might result in differences in the economic importance of forest products among them [10, 23, 25]. This obviously implies that site and livelihood specific investigations on forest dependence are necessary so that policy and management interventions targeted to support rural livelihoods and promote sustainable resource use can be tailor-made to suit intercommunity heterogeneity.

While existing studies from different dry forest areas have widen our knowledge on various aspects of forest-people interaction, there are still many other dry forest areas where empirical researches on the level of people's dependence on forests and determinant factors of forest dependence are still essential areas of research to be addressed. Ethiopia is no exception with respect to such aforementioned research needs. About 55 million ha of its land is covered by dry forests, which is its largest remaining forest vegetation [26]. These forests are largely found in the arid and semiarid lowland areas of the country, which are inhabited by rural peoples whose major livelihood strategies are traditional pastoralism and agropastoralism. Dry forests in these areas have long remained as integral components of such pastoral and agropastoral livelihood systems. However, only a few studies have so far tried to unveil the economic importance of dry forests in the country, and even such studies covered some parts of the lowland areas in three regional states, Amhara $[21,27]$, Oromia $[28,29]$, and Tigray region $[15,30]$ whereas there is a dearth of information for the dry forests of most of the areas in the Southern Nations, Nationality, and Peoples Regional State, one of which is Hammer district, the current study area.

The objectives of this study were to provide empirical evidence on the contribution of dry forest product income to the annual income of rural households. The study addressed such specific questions as the following: (i) what are the major dry forest products utilized in the study area? (ii) What is the absolute and relative contribution of dry forest income to the annual household income? (iii) Does the income contribution differ between pastoral and agropastoral livelihood types and across income groups? (iv) What factors affect household's forest income and forest income dependence?

\section{Materials and Methods}

2.1. Study Area. The study was conducted in Hammer district, found in South Omo zone of Southern Nations, Nationalities, and Peoples Regional State. Located at $839 \mathrm{~km}$ south of Addis Ababa, the country's capital, Hammer district lies between $4^{\circ} 25^{\prime}-5^{\circ} 30^{\prime} \mathrm{N}$ and $36^{\circ} 5^{\prime}-36^{\circ} 59^{\prime} \mathrm{E}$ (Figure 1). It covers an area of $5742 \mathrm{~km}^{2}$ and has a total population of 59,160 . The altitude in the district varies between 371 m.a.s.l. and 2084 m.a.s.l. [31]. The climate is dominantly a semiarid type, which covers about $95 \%$ of the area. The district has an erratic, variable rainfall and high ambient temperature ranging in $26-35^{\circ} \mathrm{C}$ [32]. The rainfall pattern is bimodal, with a primary rainy season between March and May and occasional rain between October and December. The average annual rainfall varies from $581 \mathrm{~mm}$ in the lowlands to $796 \mathrm{~mm}$ in the highland parts of the district [33].

The major land cover types in the district are forest and shrub land (39.2\%), bush land (26\%), savanna and grass land (25.7\%), and settlement and farm land (9.1\%), among which the woody vegetation accounts for significant proportion, $65.2 \%$ of the total land area of the district [33]. The major livelihood activities in the area include pastoralism (dominated by livestock production) and agropastoralism (crop and livestock production). However, the former is the dominant one, which covers approximately $75 \%$ of the area, and is commonly practiced in the southern and eastern lowland regions of the district, at altitudes below 1000 m.a.s.l. The latter, which covers small proportion of the district, is common in the highland territories in the north and northeast, with an elevation of above 1000 m.a.s.1 [31, 33].

2.2. Sampling and Data Collection. Prior to the actual survey, visits were made to the district and secondary information relevant to the study was gathered from all possible sources. Based on the baseline information documented by zonal and district agricultural offices and by previous studies [33], the district was first stratified into two: pastoral and agropastoral kebeles (administrative units of the district). Then, after a thorough discussion with experts (from South Omo Zone Agriculture and Rural Development Department, Jinka Agricultural Research Center and HWPDO), one agropastoral (Shanko-lala) and two pastoral kebeles (Angude and Mirsha-Bitagelefa) were purposively selected based on dry forest/woodland cover, representativeness, and accessibility (Figure 1). Hereafter, agropastoral and pastoral are referred to as AGPAS and PAS, respectively.

Field data collection at the selected kebeles was carried out from November 2012 to February 2013 using such methods as household survey, group discussions, market assessments, and field observation [34]. For household survey, a total of 164 households (61 from AGPAS kebele and 103 from 


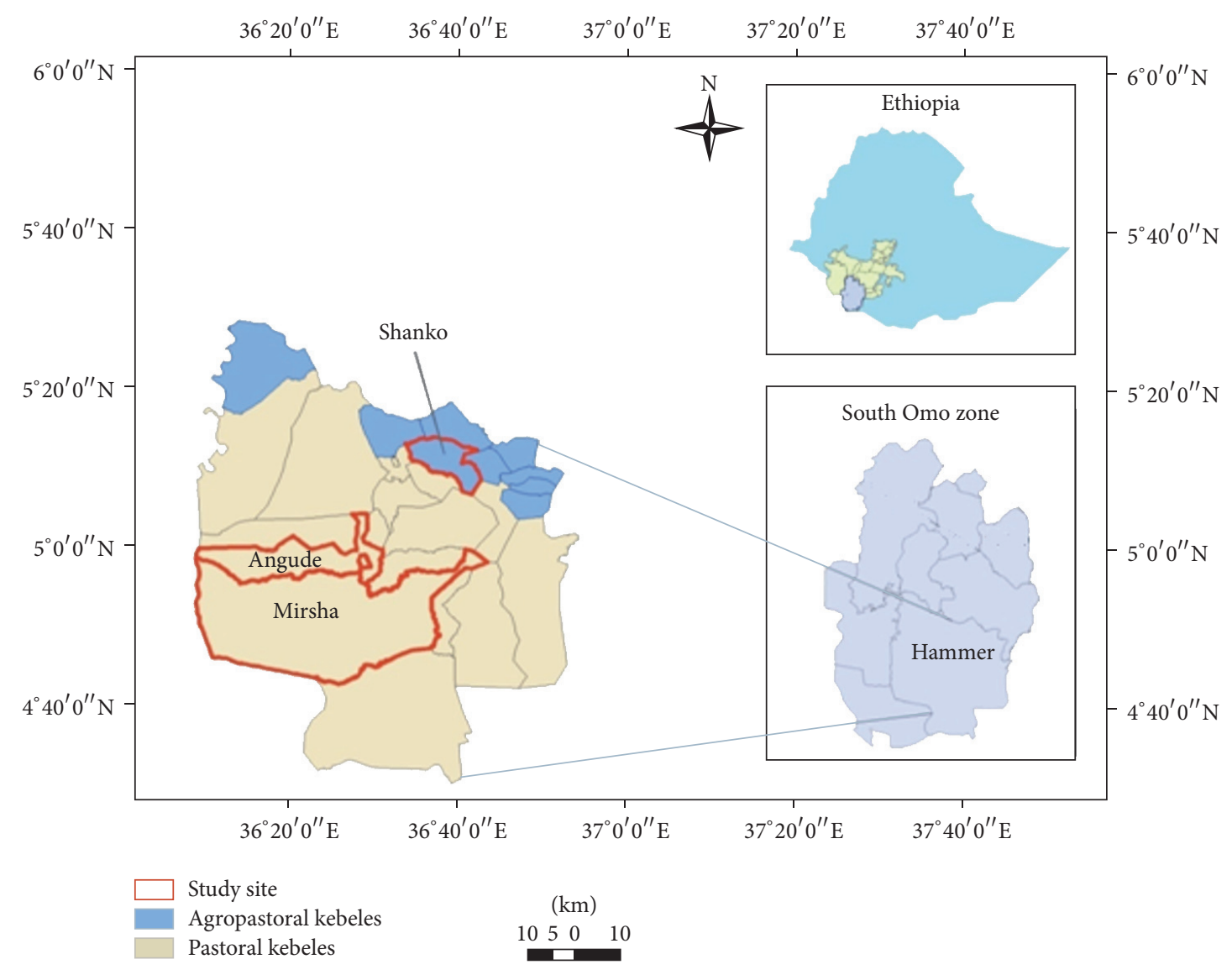

FIGURE 1: Location map of the study area.

PAS kebele, which was $10 \%$ of total households in each kebele) were sampled based on a random sampling procedure, with kebele registers used as sampling frames. The survey was carried out using a structured questionnaire aimed at capturing both qualitative and quantitative information. The questionnaire was comprised of such major issues as sociodemographic characteristics (such as sex, age, family size,and education level), major assets such as land and livestock, livelihood activities, and forest product extraction. Local enumerators were recruited from the respective sample kebeles. All enumerators were fluent speakers of the respective local languages. They were trained on data collection procedures, interviewing techniques, and the detailed contents of the questionnaire. The questionnaire was pretested to check its appropriateness for gathering all the required data.

Three group discussions, one at each selected kebele, were undertaken. Eight to twelve members were involved in the discussion, where such members include local elders, informal and formal institutional committee members, village leaders, and experts like development agents. Major points raised for discussion included several issues regarding livelihood activities; forest/woodland benefits; type and utilization of major forest products; and their socioeconomic role. During the entire discussion process, the lead author served as facilitator while insiders fully participated in the dialogue. In addition to the above methods, a rough market inventory was also conducted in some nearby local markets so as to identify the marketable forest products and record market prices of different products. Finally, field observation was carried out as a supporting data collection approach, to observe the major products collected in the forest and the respective species, particularly gum and resin bearing tree species, and also bee hives and honey products of the forest. This was done at the nearby forests in each of the three sample kebeles.

2.3. Household Income Accounting. Valuation of income from dry forests and other livelihood activities was done following Cavendish [34]. Forest products identified and included in forest income accounting were honey, fuel wood, gums and resins, hand crafts, and construction materials. The values of wild foods and fodder (grazing) were not included due to methodological difficulties. Income in this study includes both subsistence and cash incomes, calculated based on the annual (December 2011 up to December 2012) estimate of the amount produced, consumed, and sold from the different income sources. Subsistence income (the value of a product directly consumed by the household or given away to friends and relatives as gifts) was estimated using the actual market prices when available and, otherwise, surrogate market prices were used. Wherever bartering system was reported, the market price of the taken-on item was used to determine the 
value of the sold item. All costs for material inputs, hired labor, transportation, and marketing were deducted from the gross income of each income source. Family labor was not considered as a cost.

2.4. Data Analysis. The data collected from the survey was first checked. During the data checking, 17 of the 161 questionnaires were found incomplete and removed from data processing and analysis. Qualitative data were summarized by way of text analyses, while quantitative data were analyzed by descriptive and inferential statistics. Descriptive statistics, including proportions or percentages, averages, and others, were used for describing socioeconomic characteristics of sample respondents. Inferential statistics was used to study relationships between variables using different statistical tests.

To test statistical differences between AGPAS and PAS sites in the mean annual absolute and relative income, independent sample $t$-test and nonparametric Mann-Whitney test were employed, respectively. To distinguish between absolute and relative forest income among the different wealth groups, sample households were divided into three income (total annual household income) terciles, operationally categorized as first, second, and third terciles, respectively. And one-way ANOVA and Kruskal-Wallis test were run to test the difference among income groups in absolute and relative forest income, respectively.

To identify factors influencing household income from the forest, multiple linear regression analysis using Ordinary Least Square (OLS) method was employed. Two separate OLS models were used in this study: one for absolute forest income and the other for forest income dependence (measured as the relative share of forest income in the total annual household income). Different explanatory variables, hypothesized to affect forest income and income dependence, were included in the regression model [20]. Presence of multicollinearity and heteroskedasticity problems was first checked prior to running the model, and as the later problem was detected, a robust OLS model was used.

\section{Results and Discussion}

3.1. Sociodemographic Characteristics of Sample Respondents. The majority of the sample respondents (77\%) were male, while the remaining (23\%) were female. The household size of respondents ranges from two to 13 with the average of seven members. Specific to the two study sites, average household size was seven at AGPAS and six at PAS. The sample respondents were, on average, 38 and 42 years old, respectively, at AGPAS and PAS. Education level was very low in both study sites: a significant proportion of the sample respondents (88\%) do not have formal education.

Land and livestock are important fixed assets of households in the study area. On average, a household owned 2.2 ha of land (ranges from 0.25 to 6 ha) and 16.5 tropical livestock units (TLU) (ranges from 1.6 to $102.8 \mathrm{TLU}$ ). Looking into variations in the land and livestock asset holdings between the two study sites, average landholding size was 1.54 ha at AGPAS (ranges from 0.45 to 3.4 ha), whereas it was 2.64 ha at

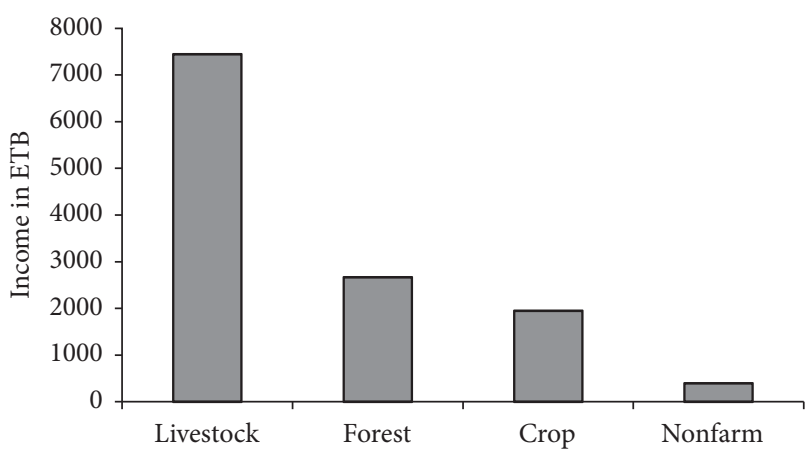

Figure 2: Major sources of annual household income and their contributions (in ETB) in the study area.

PAS (ranges from 0.25 to $6 \mathrm{ha}$ ), and the average livestock asset was 7.6 TLU at AGPAS (ranges from 1.6 to 25.3) and 21.5 TLU at PAS (ranges from 1.8 to 102.8).

3.2. Household Income and Its Sources. Households in the study areas rely on a wide range of economic activities mainly related to natural resource extraction. The major sources of income identified from the household survey were livestock, crop, forest, and nonfarm activities (such as daily labor and petty trade). Although not common, aid and remittance were mentioned as sources of livelihoods. The contribution of the major income sources to the total annual household income (the combined income generated from the main household economic activities) is presented in Figure 2. Our data showed that the average total annual income of the sample households was Ethiopian Birr (ETB) 12,450. Among the four income sources, income from livestock sector contributed the largest share (59.7\%), followed by income from forest products $(21.4 \%)$. Income from crop production and nonfarm activities accounted for $15.7 \%$ and $3.2 \%$ of the total annual household income, respectively.

3.3. Household Income from Forest Products. In the current study, livestock production dominates the livelihoods of households in the study area. In fact, as the sole source of feed for livestock was the surrounding forest which provides grasses and/or woody plants year round, this seems to signify that the forest is used as rangelands. However, the current study revealed that provision of grazing or browsing feed was not the only attribute of the dry forests, but the forest is also a source of many other products like honey, fuel wood, gums and resins, hand crafts, and construction materials, that, through their subsistence and cash income, are of importance for household livelihoods. Forest income contributes $21.4 \%$ to the total income, which was second to livestock income, even without inclusion of income from fodder and grazing. If the income from fodder and grazing was accounted, total forest income would have been higher, illustrating further the importance of forests for household income in the study area.

The $21.4 \%$ forest income share found in the current study is comparable to other studies. The share of forest income in the total annual household income was 15\% in Chiradzulu District, Malawi [35], 23\% in Gore District, Southwestern 
TABLE 1: Mean annual household income (in ETB) from different forest products.

\begin{tabular}{lcccccc}
\hline \multirow{2}{*}{$\begin{array}{l}\text { Forest } \\
\text { products }\end{array}$} & \multicolumn{2}{c}{ PAS $(N=94)$} & \multicolumn{2}{c}{ AGPAS } & \multicolumn{2}{c}{ Total } \\
& Mean & SE & Mean & SE & Mean & SE \\
\hline Honey & 1448.5 & 116.6 & 1117.92 & 228.13 & 1329.32 & 111.3 \\
Fuel wood & 1005.5 & 108.8 & 1128.08 & 178.01 & 1049.72 & 94.4 \\
Gum-resin & 237.4 & 25.1 & - & - & 151.83 & 18.6 \\
Other & 136.1 & 10.50 & 146.54 & 12.99 & 139.83 & 8.2 \\
products & & & & & & \\
\hline Total forest & 2827.5 & 124.6 & 2392.5 & 289.5 & 2670.7 & 132 \\
\hline
\end{tabular}

Ethiopia [36], and up to $22 \%$ in Africa, Asia, and Latin America [37]. However, it is also relatively lower than the share reported from other studies conducted in other arid and semiarid areas of Ethiopia. For instance, Worku et al. [38] found a $34 \%$ annual income contribution from dry forests in Somali region, Southeastern Ethiopia. In Wenbera district, Northwestern Ethiopia, income from dry forests contributed 39\% of the total annual household income [39]. $32 \%$ of the annual household income in Somali region, Eastern Ethiopia, was obtained from the collection and sale of one forest product, Gum-resin [28]. The lower income share in the current study compared with the aforementioned studies could likely be attributed to the low engagement of households in extraction activities, and most importantly to the limited enabling production and marketing environment in the current study area, particularly for some economically valuable products such as gum and resin.

3.3.1. Major Forest Products: Use, Collection, and Income. As indicated earlier, the forest provides different products that, through their subsistence and cash income, are of importance for household livelihoods. The major products include honey, fuel wood, gum and resin, hand crafts, and construction materials, and the first three were the top three important products in terms of their contribution to household income (Table 1). The description of the collection and production of these major products and respective income contribution are presented below.

Honey. In the current study, about 61 and $68 \%$ of sample households at the AGPAS and PAS site indicated the production of honey as one of their forest based livelihood activities. According to the household survey, honey production in the study areas was mainly carried out by placing hives hanged in a forest. Honey from the forest is produced/harvested three to five times annually; and three to five Kilograms of honey can be produced in one bee hive in one harvest. As reported during the survey, households delivered the raw honey to the nearby market, without product processing or any other value adding activity. The raw honey was reported to be sold at an average price of ETB 40 per $\mathrm{kg}$.

Income from honey contributed a significant proportion of the annual forest income of households at both study sites: of the total forest income of 2390 ETB at AGPAS and
2827 ETB at PAS, honey accounted for 47 and 51\% (Table 1). In fact, being a much-valued product from forested areas, collection and production of honey from the forest have been reported as one of the most important forest based livelihood activities around the world [40]. In Ethiopia, rural households engagement in honey production from hives hanged in a forest has been widely reported for humid and subhumid forest areas of the country, particularly the southern and southwestern areas endowed with natural high forest [41-43], whereas it has seldom been reported for arid and semiarid lowland areas. For instance, no engagement in honey production was reported from studies conducted in the dry forests of Liben and Afdher districts, south eastern dry lands [38], and in Quara (northwestern), AsgedeTsimbla (northern), and Yabelo (southern) lowlands [22]. Likewise, Abebaw et al. [21] found few households engaged in honey production from the dry forest of Metema district, northwestern region. Though it is implicit to justify the variation between the finding of the current study and the aforementioned ones, the current study confirmed that the dry forests have the potential to provide honey as the humid forests do.

Fuel Wood. Income from fuel wood collection was the second most important forest income; it accounted for 47 and $36 \%$ of the annual forest income at AGPAS and PAS, respectively (Table 1). Given that fuel wood has remained as the major energy sources for most of the rural as well as urban households, coupled with the relentless population growth and the subsequent increase in wood demand, it might not be uncommon to find fuel wood harvesting as a major forest based livelihood activity. During group discussion, participants stated that the activity of fuel wood collection for income generation has become common and that the emerging and growing market demand, which was the result of expansion of nearby towns and increment of urban population, was one of the major responsible factors for such activity. Extraction of fuel wood from the forest was reported as a major source of forest related incomes for rural households in different parts of Ethiopia [21, 22, 44]. In Malawi, Chilongo [45] found that fuel wood harvest is the dominant forest related activities and attached this to the fact that fuel wood is the main source of cooking energy in the country. A global assessment also shows the dominant role of fuel wood in forest environmental incomes for the rural poor [37].

Gums and Resins (GR). Gums and resins (GR) are one of the most economically valuable products of dry forests of several regions. In the current study, collection and sale of GR products as a source of income were observed only at PAS study site. In this study site, households extracted GR from different species. The most commonly known GR product was frankincense collected from Boswellia neglecta, which is locally named as "tikuretan" (meaning: black incense). Next to frankincense, gum-resins from four Commiphora species, Commiphora africana, C. myrrh, C. habessinica, and C. schimperi were the major products collected and utilized in the study area, and products from all species are locally 
TABLE 2: Mean annual income (in ETB) of pastoral and agropastoral households from different sources.

\begin{tabular}{|c|c|c|c|c|c|c|}
\hline \multirow{2}{*}{ Sources } & \multicolumn{2}{|c|}{$\operatorname{AGPAS}(N=53)$} & \multicolumn{2}{|c|}{$\operatorname{PAS}(N=94)$} & \multicolumn{2}{|c|}{ Comparison test } \\
\hline & Mean \pm SE & $\%$ & Mean \pm SE & $\%$ & ${ }^{\mathrm{a}} t$ value $(\mathrm{df})$ & ${ }^{\mathrm{b}} Z$ value \\
\hline (1) Livestock income & $6969.75 \pm 681.37$ & 54.5 & $7716.99 \pm 597.3$ & 62.73 & $0.79(145)$ & -1.85 \\
\hline (2) Forest income & $2392.55 \pm 289.51$ & 18.4 & $2827.53 \pm 124.6$ & 22.99 & $1.38(72)$ & $-3.24^{*}$ \\
\hline (3) Crop income & $2981.21 \pm 195.66$ & 23.4 & $1371.94 \pm 49.2$ & 11.15 & $7.98(59)^{*}$ & $-5.25^{*}$ \\
\hline (4) Nonfarm income & $424.4 \pm 125.11$ & 3.5 & $385.09 \pm 71.6$ & 3.13 & $0.29(145)$ & -1.11 \\
\hline Total & $12767.9 \pm 838.49$ & & $12301.5 \pm 666.9$ & & $0.43(145)$ & \\
\hline
\end{tabular}

a: Independent sample $t$-test for difference in absolute income; the test for forest income and crop income was based on unequal variance. b: Mann-Whitney test for difference in relative income (percentage). * Significant at $p<0.001$; df: degree of freedom.

named as "nechetan" (meaning: white incense). Production and/or harvesting of the product is mainly done by collecting the naturally oozed product from the trunk and branches of the tree, as well as from the ground. Artificial tapping was not common in the study area. No specialized production techniques, product handling cares, and product processing were observed in the study. Collectors simply collected the product, made the fresh product have a ball-like structure (sometimes they also use dry ash so as to avoid cracking), and delivered it to the nearby market. The average annual income from GR was estimated to be 152 ETB (Table 1).

GR extraction as local income source is in fact reported in different parts of Ethiopia's lowland forest areas, particularly in the country's northern, northwestern, southern, and southeastern areas $[21,38,41,46]$; however, the level of people's participation in GR production and the estimated GR income in the current study is relatively lower than that reported in most of these previous studies. One major attributable factor for this can be (though differences in resource base might exist) the lack of enabling production and marketing environment in the current study area as compared to others. For instance, in most of the northern forested areas, there are many private and state companies engaged in the production and marketing of GR, and they create seasonal employment for the tapping, collection, and grading of frankincense [41, 46, 47]. On the other hand, Ethiopian Natural Gum Production and Marketing Enterprise (ENGPME), which has been the main actor in the gum and resin business in Ethiopia since its origin, is playing a major role in GR production and marketing through establishing its own production areas in the different localities in the northern and northwestern parts of the country, as well as a major buyer of GRs from individual rural collectors and cooperatives in the south and southeastern parts of the country [39]. In the current study area, information from group discussion showed that ENGPME has established one of its own warehouse sites at the study area in 1989 and started buying GR from individual pastoralists. However, soon after pastoral households had increasingly engaged in the collection and sale of GR, the company, ENGPME, has left the area. Besides, with the last few years' effort to organize rural households in the form of cooperatives and engage them as new actors in the frankincense supply chain, households in Northern and Southern Ethiopia formed cooperatives and earned direct income from the sale of GR [29, 39, 46,
47]. In our study area, until the time when data collection was conducted, no intervention has been made regarding the initiation and mobilization of pastoralists to establish cooperatives.

\subsection{Forest Income and Its Contribution: Comparison between} Pastoral and Agropastorals. Important finding in the current study was that the absolute and relative forest and all other three income components differed between the households of AGPAS and PAS sites (Table 2). While income from livestock production took the lion share in both cases, its contribution was slightly higher at PAS (63\%) than at AGPAS (54\%), which confirms the fact that pastoralism is a livestock dominated livelihood. Likewise, while income from crop production was the second share $(23 \%)$ at AGPAS, its importance was relatively lower at PAS (11\%). With regard to forest income, with average share of $18 \%$ and $23 \%$ income from forest was second to livestock income at PAS, whereas it was third after livestock and crops at AGPAS, respectively. Though differences in the amount and share of income between the two sites were observed for all income sources, statistically significant differences were found only in the cases of absolute crop income, relative crop income, and relative forest income, all at $p<0.01$ (Table 2).

The higher dependency on forest income of pastoralists as compared to agropastoralists could be attributed by different factors. For instance, it might be related to time and labor resource: the engagement of agropastoralists in crop farming may reduce time as well as labor resources for forest product collection, whereas pastoralists may not face such scarcity of time and labor as livestock production is relatively less labor intensive and/or as forest product collection could be carried out parallel to livestock rearing activities. On the other hand, the increasing sedentarization in agropastoral areas and the subsequent forest clearance for crop cultivation may reduce the forest resource base and hence reduce the amount that could be extracted from the forest. A study in Liben and Afdher, Southeastern Ethiopia, found that pastoral households earned more dry forest income than agropastoralists, and it mentioned labor scarcity due to competing agriculture and distance to the forest as factors hindering agropastoralists' dry forest income [38]. The same study also reported that the mobility of pastoralists also allowed them to cover wider areas of forests with species that bear valuable products such as gums and resins. Similarly, a study conducted in arid and 


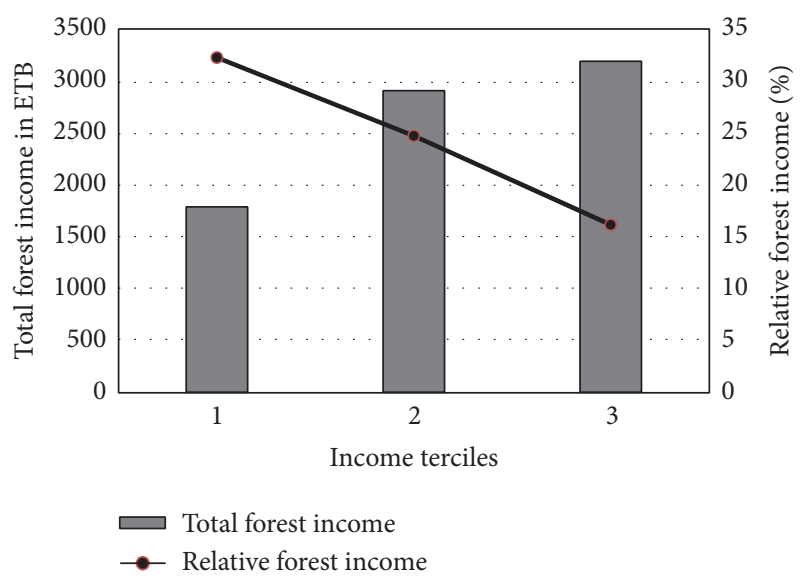

Figure 3: Total and relative forest income (in ETB) across income tercile groups.

semiarid areas of Afar, Eastern Ethiopia, revealed that since pastoralism is more compatible with forest based activities in terms of labor allocation, pastoral households earn more forest income than agropastorals [48].

\subsection{Forest Income and Its Contribution: Comparison among} Income Groups. Splitting the sample respondents into three income terciles based on total annual household income, the study examined how important the forest is for different wealth classes in terms of its absolute as well as relative income. As shown in Figure 3, it is the upper income group that obtained higher dry forest income $(3232 \pm 283)$, followed by middle group $(2955 \pm 181)$. The lowest wealth group earned the least income $(1825 \pm 151)$. Such variation in dry forest income among income groups was statistically significant $(p<0.001)$. In contrast to the trend observed in mean dry forest income which increased with total household income, the share of forest income decreased with higher total annual household income (Figure 3). The lower income group generated $32.4 \%$, middle $24.8 \%$, and upper $16 \%$ of their income from forest. The Kruskal-Wallis test revealed that such variation in the share of forest income among the three income groups was statistically significant (Chi-square: 31.1, $2, p<0.000$ ). Looking into product specific income, the study found no clear trends between income groups and the collected dry forest product type.

The finding implies that households with higher total annual income extracted more forest products than those with lower income, but they are relatively less dependent on forest products than the lower counterpart. This may be due to the fact that poor households have fewer assets in terms of land, livestock, and cash to generate more income from agriculture, or in other words, since they have only minimal access to farmland and livestock assets, they may have no chance to replace extraction of forest products by adequate production of agricultural products. Thus they tend to depend more on forests. Similar trends were reported in other studies $[15,23,24,38]$ while there are also contrasting results showing that poorer households extracted more forest products and are more dependent on forest products than wealthier one $[8,22]$.

Another important inference regarding the wealth-forest income link can also be given here. For instance, the greater average number of forest product collectors in all income groups in this study indicates that forest products in the study area are used in support of current basic consumptions. On the other hand, the results that lower income groups obtained low income but had high dependency on forest products imply that forest product extraction primarily serves poorer households as a gap-filling activity or as a safety net in times of crisis while remaining a low return activity. Bognetteau and Wirtu [49] stated that "... for the poorer households, forest products usually contribute less in financial terms, but they are an important safety net, especially through the open access situation of some of these products."

3.6. Determinants of Forest Income and Forest Income Dependence. Two separate multiple linear regression models were carried out to identify factors influencing (i) households' annual forest income and (ii) households' level of dependency on forest income. The result is presented in Table 3. All explanatory variables, except household head's age, were found to have a statistically significant effect in one or both of the two (forest income and income dependency) models.

To start with site factor, its effect on forest income was not statistically significant, whereas it had a significant and positive influence $(p<0.01)$ on dependency, which implied that the level of dependency on forest income increased with the likely of the households to be pastoral and this supported the mean comparison test indicated previously. Sex of the household head (being male) had a significant and negative influence $(p<0.05)$ on forest dependency, while its effect on forest income was not statistically significant. According to the analysis result, a female headed household is more likely to be forest-dependent than a male headed household. As suggested in the forest dependence literature, women are likely to participate more in common property resources than men and may be more involved in gathering activities than men [50]. The finding of the current study regarding sex is in line with other studies [30,44,51].

Family size significantly influenced both the forest income and level of dependency on forest income $(p<0.05)$ where an increase in family size resulted in an increased income and dependency. This may be related to the need to have additional income (in addition to main livelihood activities) so as to support larger number families, and on the other hand, the quantity of production may rise as more number of household members is engaged in product collection, and hence the income may increase. This finding is in line with others such as $[9,38,52]$.

The two important household assets, land and livestock size, were found to influence forest income and dependency negatively; however, their effect on income was not significant. According to the regression result, larger landholding size and livestock asset significantly decreased (both at $p<$ 0.01 ) the level of dependency on forest income. Given that larger land and livestock resources may reflect higher total income, the negative sign would seem to contradict our 
TABLE 3: OLS regression of household forest income (A) and forest income dependence (B) against socioeconomic characteristics.

\begin{tabular}{|c|c|c|c|c|c|c|c|c|}
\hline \multirow{2}{*}{ Factor } & \multicolumn{4}{|c|}{ (A) Forest income } & \multicolumn{4}{|c|}{ (B) Forest income dependence } \\
\hline & Coefficient & SE & $t$-value & $p$ value & Coefficient & SE & $t$-value & $p$ value \\
\hline Constant & 1463.596 & 1576.25 & 0.929 & 0.355 & 19.99 & 13.603 & 1.47 & 0.144 \\
\hline Site (dummy, 1 if pastoral site) & 494.499 & 534.478 & 0.929 & 0.357 & 13.083 & 5.074 & 2.578 & $0.011^{*}$ \\
\hline Sex of household head (dummy, 1 if male) & -77.247 & 271.202 & -0.285 & 0.776 & -7.276 & 3.175 & -2.292 & $0.023^{*}$ \\
\hline Age of household head (yrs) & 25.948 & 17.918 & 1.448 & 0.15 & 0.014 & 0.178 & 0.079 & 0.94 \\
\hline Household size (number) & 258.303 & 106.476 & 2.426 & 0.017 & 1.409 & 0.672 & 2.097 & $0.038^{*}$ \\
\hline Land size (in hectare) & -156.805 & 113.184 & -1.385 & 0.168 & -2.358 & 0.7 & -3.369 & $0.001^{* *}$ \\
\hline TLU (tropical livestock unit) & -10.95 & 17.621 & -0.621 & 0.535 & -0.655 & 0.171 & -3.83 & 0 \\
\hline TLU squared & 0.066 & 0.137 & 0.482 & 0.632 & 0.005 & 0.001 & 3.25 & $0.001^{* *}$ \\
\hline Access to extension (dummy, 1 if yes) & 949.616 & 303.252 & 3.131 & $0.002^{* *}$ & 6.268 & 2.611 & 2.401 & $0.018^{*}$ \\
\hline Nonfarm activity (dummy, 1 if yes) & -672.183 & 224.207 & -2.998 & $0.003^{* *}$ & -5.623 & 2.019 & -2.785 & $0.006^{* *}$ \\
\hline Distance to market (in km) & -152.298 & 49.471 & -3.079 & $0.003^{* *}$ & -0.728 & 0.503 & -1.447 & 0.15 \\
\hline Distance to forest (in km) & -315.238 & 121.513 & -2.594 & $0.011^{*}$ & -1.328 & 1.154 & -1.151 & 0.252 \\
\hline$R$-square & \multicolumn{4}{|c|}{0.41} & \multicolumn{4}{|c|}{0.37} \\
\hline$F$-value & \multicolumn{4}{|c|}{12.27} & \multicolumn{4}{|c|}{5.42} \\
\hline$p$ value & \multicolumn{4}{|c|}{0.000} & \multicolumn{4}{|c|}{0.000} \\
\hline
\end{tabular}

${ }^{*}$ Significant at $5 \% .{ }^{* *}$ Significant at $1 \%$.

earlier findings that high income households extracted more forest products. However, since the relation is insignificant, it cannot possibly be a contradiction. The significant negative effect of these assets on dependency confirmed the earlier finding that rich households are less dependent on forest income than the poor ones. Similar finding was reported by Fisher [13] and McElwee [53].

On the other hand, the regression result for nonfarm activity supported the hypothesis that availability of nonfarm activity reduces the need for environmental income: households with nonfarm activity were found to earn higher forest income $(p<0.01)$ and to be more dependent on forest income $(p<0.01)$ than those without. This can possibly be because engagement in other income generating activities like nonfarm may reduce quantity of extraction and hence income, by competing for and taking over labor as well as time that would otherwise be invested for forest related activities.

Extension contact was the other important factor that significantly affected both absolute forest income and income dependence $(p<0.01)$. Households having an extension contact are more likely to earn higher forest income and to be more dependent on forest income. Even though extension service was not so far pronounced in the study area, the positive influence of these services on forest income can be an indication of how the presence of encouraging and enabling environment is important for rural dwellers to better obtain substantial returns from forest product extraction. Similar to this finding, Gebrelibanos [54] found that frequency of extension contact has a positive and significant impact in adopting specific technology or getting new information.

Forest income showed significant reduction with increasing distance to the forest $(p<0.05)$ and to the market $(p<0.01)$. The larger the distance from the forest the lower the income from forest: obviously, this is related to less or limited access to the resource and associated time and energy costs, both of which became significant with increasing distance from the forest. Particular to the study area: large distance from the forest coupled with the poor infrastructural situation and the unsuitable terrain of the area limit the quantity of extraction. The negative relationship between income and distance to forest is also in agreement with the report of Abebaw et al. [21] for Metema district in northwestern Ethiopia and Asfaw et al. [44] for Jelo Afromontane forest of Eastern Ethiopia. Regarding market distance, forest income is higher for those who are near to the market place than those far away, which may be related to the incurrence of time and transportation costs, as well as to the lack of or limited access to market information. Such negative influence of market distance in the current study has also been observed in different studies $[9,38,55]$.

\section{Conclusion and Recommendations}

The livelihood of the people in the study area depends on livestock rearing, crop production, forest product collection, and nonfarm activities. Livestock sector plays the dominant role in livelihoods of both pastoral and agropastoral households, while income from forest products supplements livestock dominated livelihoods. Pastoral households are relatively more dependent on forest related incomes than agropastoral households. Honey, fuel wood, GR, hand crafts, and construction materials are the five major forest income sources, where the top three products in terms of contribution to household income are honey, fuel wood, and GR. Forest income and dependency vary with household characteristics. Households with higher total annual income obtain more forest income than those with lower income, but they are relatively less dependent on forest products than the lower counterpart. Being pastoral and female headed household increases the level of dependency on forest income, while having larger land and livestock size reduces dependency. 
Distance to forest and market reduces total forest income. Larger family size, no nonfarm activity, and access to extension contact increase both forest income and forest income dependency.

Based on the above findings, some important implications can be drawn. First, our results illustrate that forest products continue to play important role in the livelihood of pastoral and agropastoral communities of the dry land areas. Such important role of dry forests should be given a due focus in development and land use policies, because making and implementing policies that do not consider the role of forests may result in policy outcomes that do not harmonize development and conservation objectives.

Second, as far as improving household livelihoods and alleviating poverty in the study site are concerned, the present result on wealth-forest income link suggests that enhancing forest product collection and marketing for lower income households should certainly be encouraged as part of an overall strategy. Likewise, results from the regression analysis of determinants of forest income and income dependency equally offer a host of policy options open to forest conservation and management in the study area.

Third, dry forest of the study area is home to high value products such as honey and GR for which there are potential opportunities that could be explored further and might contribute in greater extents to household incomes. For this, awareness creation and capacity building for households on the production, harvesting, handling, and value-addition of these economically valuable products should be the major future intervention areas. Moreover, given that Ethiopia is known as being one of the major producers and sellers of honey and GR products and these products are enjoying fortunate market and technological opportunities, creating and promoting better commercialization environment in the study area would further lend additional weight to the existing contribution of these products to the national economy.

Finally, future attempts should be made to estimate and value the contribution of other nonmarketable products that have not been included in the current study (such as fodder and grazing) to enhance the economic contributions of dry forests to the local livelihoods and to the national economy at large.

\section{Competing Interests}

The authors declare that there is no conflict of interests regarding the publication of this paper.

\section{Acknowledgments}

The authors are grateful for the financial support from The Spanish Agency for International Development Cooperation (AECID). They also would like to express their gratitude to Ethiopian Environment and Forestry Research Institute (formerly, Forestry Research Center) for its institutional support. They are thankful to the local people of Shankolala, Angude, and Mirsha kebeles for granting them their valuable time and support during the study. Special thanks are also due to experts and officials from Jinka Agricultural Research Center, South Omo Zone Agriculture Department, Hammer District Pastoral Development Office, and Hammer District Administration Office, for their support during data collection. Finally, they are very pleased to thank Ms. Iria Soto for her invaluable technical support for this research.

\section{References}

[1] E. Mwangi and S. Dohrn, Biting the Bullet: How to Secure Access to Dry Lands Resources for Multiple Users, International Food Policy Research Institute, Washington, DC, USA, 2006.

[2] T. Oksanen, B. Pajari, and T. Tuomasjukka, Eds., Proceedings from Forests in Poverty Reduction Strategies: Capturing the Potential, Proceedings no. 47, European Forest Institute, Joensuu, Finland, 2003.

[3] F. Paumgarten and C. M. Shackleton, "Wealth differentiation in household use and trade in non-timber forest products in South Africa," Ecological Economics, vol. 68, no. 12, pp. 29502959, 2009.

[4] S. Shackleton, B. Campbell, H. Lotz-Sisitka, and C. Shackleton, "Links between the local trade in natural products, livelihoods and poverty alleviation in a semi-arid region of South Africa," World Development, vol. 36, no. 3, pp. 505-526, 2008.

[5] L. Petheram, B. Campbell, C. Marunda, D. Tiveau, and S. Shackleton, "The wealth of the dry forests. Can sound forest management contribute to the Millennium Development Goals in sub-Saharan Africa?" Forest Livelihood Briefs 4, CIFOR, Bogor, Indonesia, 2006.

[6] CIFOR, Thinking beyond the Canopy. CIFOR Annual Report, CIFOR, Bongor, Chad, 2008.

[7] W. Cavendish and B. M. Campbell, Poverty, Environmental Income and Rural Inequality: A Case Study from Zimbabwe, Centre for International Forestry Research, Bogor, Indonesia, 2002.

[8] C. Shackleton and S. Shackleton, "The importance of nontimber forest products in rural livelihood security and as safety nets: a review of evidence from South Africa," South African Journal of Science, vol. 100, no. 11-12, pp. 658-664, 2004.

[9] G. Mamo, E. Sjaastad, and P. Vedeld, "Economic dependence on forest resources: a case from Dendi District, Ethiopia," Forest Policy and Economics, vol. 9, no. 8, pp. 916-927, 2007.

[10] G. Thondhlana, P. Vedeld, and S. Shackleton, "Natural resource use, income and dependence among San and Mier communities bordering Kgalagadi Transfrontier Park, southern Kalahari, South Africa," International Journal of Sustainable Development and World Ecology, vol. 19, no. 5, pp. 460-470, 2012.

[11] W. Cavendish, "Empirical regularities in the povertyenvironment relationship of rural households: evidence from Zimbabwe," World Development, vol. 28, no. 11, pp. 1979-2003, 2000 .

[12] E. Sjaastad, A. Angelsen, P. Vedeld, and J. Bojö, "What is environmental income?” Ecological Economics, vol. 55, no. 1, pp. 37-46, 2005.

[13] M. Fisher, "Household welfare and forest dependence in southern Malawi," Environment and Development Economics, vol. 9, no. 1, pp. 135-154, 2004.

[14] C. M. Shackleton, S. E. Shackleton, E. Buiten, and N. Bird, "The importance of dry woodlands and forests in rural livelihoods and poverty alleviation in South Africa," Forest Policy and Economics, vol. 9, no. 5, pp. 558-577, 2007. 
[15] B. Babulo, B. Muys, F. Nega et al., "Household livelihood strategies and forest dependence in the highlands of Tigray, Northern Ethiopia," Agricultural Systems, vol. 98, no. 2, pp. 147-155, 2008.

[16] M. Appiah, D. Blay, L. Damnyag, F. K. Dwomoh, A. Pappinen, and O. Luukkanen, "Dependence on forest resources and tropical deforestation in Ghana," Environment, Development and Sustainability, vol. 11, no. 3, pp. 471-487, 2009.

[17] J. C. Tieguhong and E. M. Nkamgnia, "Household dependence on forests around Lobeke National Park, Cameroon," International Forestry Review, vol. 14, no. 2, pp. 196-212, 2012.

[18] T. Yemiru, A. Roos, B. M. Campbell, and F. Bohlin, "Forest incomes and poverty alleviation under participatory forest management in the bale highlands, Southern Ethiopia," International Forestry Review, vol. 12, no. 1, pp. 66-77, 2010.

[19] J. A. Timko, P. O. Waeber, and R. A. Kozak, "The socioeconomic contribution of non-timber forest products to rural livelihoods in Sub-Saharan Africa: knowledge gaps and new directions," International Forestry Review, vol. 12, no. 3, pp. 284294, 2010

[20] S. P. Kar and M. G. Jacobson, "NTFP income contribution to household economy and related socio-economic factors: lessons from Bangladesh," Forest Policy and Economics, vol. 14, no. 1, pp. 136-142, 2012.

[21] D. Abebaw, H. Kassa, G. T. Kassie, M. Lemenih, B. Campbell, and W. Teka, "Dry forest based livelihoods in resettlement areas of Northwestern Ethiopia," Forest Policy and Economics, vol. 20, pp. 72-77, 2012.

[22] B. Teshome, H. Kassa, Z. Mohammed, and C. Padoch, "Contribution of dry forest products to household income and determinants of forest income levels in the Northwestern and Southern Lowlands of Ethiopia," Natural Resources, vol. 06, no. 05, pp. 331-338, 2015.

[23] K. Heubach, R. Wittig, E.-A. Nuppenau, and K. Hahn, "The economic importance of non-timber forest products (NTFPs) for livelihood maintenance of rural west African communities: a case study from northern Benin," Ecological Economics, vol. 70, no. 11, pp. 1991-2001, 2011.

[24] M. R. Nielsen, M. Pouliot, and R. K. Bakkegaard, "Combining income and assets measures to include the transitory nature of poverty in assessments of forest dependence: evidence from the Democratic Republic of Congo," Ecological Economics, vol. 78, pp. 37-46, 2012.

[25] G. Thondhlana, S. Shackleton, and E. Muchapondwa, "Kgalagadi Transfrontier Park and its land claimants: a pre-and postland claim conservation and development history," Environmental Research Letters, vol. 6, no. 2, Article ID 024009, pp. 1-12, 2011.

[26] M. Lemenih, T. Abebe, and M. Olsson, "Gum and resin resources from some Acacia, Boswellia and Commiphora species and their economic contribution in Liben, Southeastern Ethiopia," Journal of Arid Environment, vol. 56, pp. 146-166, 2003.

[27] A. Eshete, D. Teketay, and H. Hakan, "The socio-economic importance and status of populations of Boswellia papyrifera (Del.) Hochst. In Northern Ethiopia: the case of north gonder zone," Forests, Trees and Livelihoods, vol. 15, no. 1, pp. 55-74, 2005.

[28] M. Lemenih and F. Bonger, "Dry forests of Ethiopia and their silviculture," in Silviculture in the Tropics, Tropical Forestry, S. Günter, M. Weber, B. Stimm, and R. Mosandi, Eds., pp. 261-272, Springer, Berlin, Germany, 2011.
[29] A. Worku, M. Lemenih, M. Fetene, and D. Teketay, "Socioeconomic importance of gum and resin resources in the dry woodlands of Borana, southern Ethiopia," Forests Trees and Livelihoods, vol. 20, no. 2-3, pp. 137-156, 2011.

[30] B. Babulo, B. Muys, F. Nega et al., "The economic contribution of forest resource use to rural livelihoods in Tigray, Northern Ethiopia," Forest Policy and Economics, vol. 11, no. 2, pp. 109-117, 2009.

[31] HWPDO, Hammer Woreda Pastoralist Development Office. Different Reports and Archives in the Office, Dimeka, Hammer Woreda, Ethiopia, 2012.

[32] A. Terefe, A. Ebro, and T. Zewedu, "Rangeland dynamics in South Omo zone of Southern Ethiopia: assessment of rangeland condition in relation to altitude and grazing types," Livestock Research for Rural Development, vol. 22, no. 10, pp. 1-12, 2010.

[33] T. A. Belay, Ø. Totland, and S. R. Moe, "Woody vegetation dynamics in the rangelands of lower Omo region, Southwestern Ethiopia," Journal of Arid Environments, vol. 89, pp. 94-102, 2013.

[34] W. Cavendish, "Qualitative methods for estimating the economic value of resource use to rural households," in Uncovering the Hidden Harvest, B. M. Campbell and M. K. Luckert, Eds., pp. 17-63, Earthscan, London, UK, 2002.

[35] P. Kamanga, P. Vedeld, and E. Sjaastad, "Forest incomes and rural livelihoods in Chiradzulu District, Malawi," Ecological Economics, vol. 68, no. 3, pp. 613-624, 2009.

[36] B. Debela, Contribution of Non-timber forest products to the rural household economy: gore District, Southwestern Ethiopia [M.S. thesis], Hawassa University Wondo Genet College Of Forestry and Natural Resources, Ethiopia, Ethiopia, 2004.

[37] P. Vedeld, A. Angelsen, E. Sjaastad, and G. K. Berg, Counting on the Environment: Forest Incomes and the Rural Poor, Environmental Economics Series Paper No. 98, The World Bank, Washington, DC, USA, 2004.

[38] A. Worku, J. Pretzsch, H. Kassa, and E. Auch, “The significance of dry forest income for livelihood resilience: the case of the pastoralists and agro-pastoralists in the drylands of southeastern Ethiopia," Forest Policy and Economics, vol. 41, pp. 51-59, 2014.

[39] Z. Mekonnen, A. Worku, T. Yohannes, T. Bahru, T. Mebratu, and D. Teketay, "Economic contribution of gum and resin resources to household livelihoods in selected regions and the national economy of Ethiopia," Ethnobotany Research \& Applications, vol. 11, pp. 273-288, 2013.

[40] A. Mohammed, W. Tadesse, and A. Yadessa, "Counting on forests: non-timber forest products and their role in the households and national economy in Ethiopia," in Commercialization of Ethiopian Agriculture. Proceedings of the 8th Annual Conference of Agricultural Economics Society of Ethiopia, February 24-26, 2005, pp. 179-196, Agricultural Economics Society of Ethiopia (AESE), Addis Ababa, Ethiopia, 2006.

[41] B. Desalegn, "Assessment of the effect of ant (Dorylus fulvus) on honeybee colony (A. mellifera) and their products in west and South-West Shewa Zones, Ethiopia," Ethiopian Journal of Animal Production, vol. 7, no. 1, pp. 12-26, 2007.

[42] A. Shiferaw, M. Jaleta, B. Gebremedhin, and D. Hoekstra, Increasing Economic Benefit from Apiculture through Value Chain Development Approach: The Case of Alaba Special District, Southern Ethiopia, IPMS Ethiopia, 2010.

[43] C. Kinati, T. Tolemariam, K. Debele, and T. Tolosa, "Opportunities and challenges of honey production in Gomma district of Jimma zone, South-West Ethiopia," Journal of Agricultural Extension and Rural Development, vol. 4, no. 4, pp. 85-91, 2012. 
[44] A. Asfaw, M. Lemenih, H. Kassa, and Z. Ewnetu, "Importance, determinants and gender dimensions of forest income in eastern highlands of Ethiopia: the case of communities around Jelo Afromontane forest," Forest Policy and Economics, vol. 28, pp. 1-7, 2013.

[45] T. Chilongo, "Livelihood strategies and forest reliance in Malawi," Forests Trees and Livelihoods, vol. 23, no. 3, pp. 188210, 2014.

[46] M. Tilahun, L. Vranken, B. Muys et al., Rural Households' Demand for Frankincense Forest Conservation in Tigray: A Contingent Valuation Analysis, Bioeconomics Working Paper Series, Working Paper No. 2, Division of Bioeconmics Department of Earth and Environmental Sciences University of Leuven GeoInstitute, Leuven, Belgium, 2012.

[47] M. Lemenih, H. Kassa, G. T. Kassie, D. Abebaw, and W. Teka, "Resettlement and woodland management problems and options: a case study from North-Western Ethiopia," Land Degradation and Development, vol. 25, no. 4, pp. 305-318, 2014.

[48] D. Tsegaye, P. Vedeld, and S. R. Moe, "Pastoralists and livelihoods: a case study from northern Afar, Ethiopia," Journal of Arid Environments, vol. 91, pp. 138-146, 2013.

[49] E. Bognetteau and O. Wirtu, "Certification and market development for NTFPs: an option for sustainability," NTFP Research \& Development in South-West Ethiopia Project, Policy Briefing Note 3, 2007.

[50] U. Narain, S. Gupta, and K. van't Veld, "Poverty and the environment: exploring the relationship between household incomes, private assets, and natural assets," Land Economics, vol. 84, no. 1, pp. 148-167, 2008.

[51] A. Mohamed, The contribution of non-timber forest products to rural livelihood in southwest Ethiopia [M.S. thesis], Wageningen University and Research Center, Wageningen, The Netherlands, 2007.

[52] W. M. Fonta, H. E. Ichoku, and E. Ayuk, "The distributional impacts of forest income on household welfare in rural Nigeria," Journal of Economics and Sustainable Development, vol. 2, no. 2, pp. 1-13, 2011.

[53] P. D. McElwee, "Forest environmental income in Vietnam: household socioeconomic factors influencing forest use," Environmental Conservation, vol. 35, no. 2, pp. 147-159, 2008.

[54] A. Gebrelibanos, Farmer's perception and adoption of integrated striga management technology in tahatay adiabo woreda, Tigray, Ethiopia [M.S. thesis], Haramaya University, 2006.

[55] E. Melaku, Z. Ewnetu, and D. Teketay, "Non-timber forest products and household incomes in Bonga forest area, southwestern Ethiopia," Journal of Forestry Research, vol. 25, no. 1, pp. 215-223, 2014. 

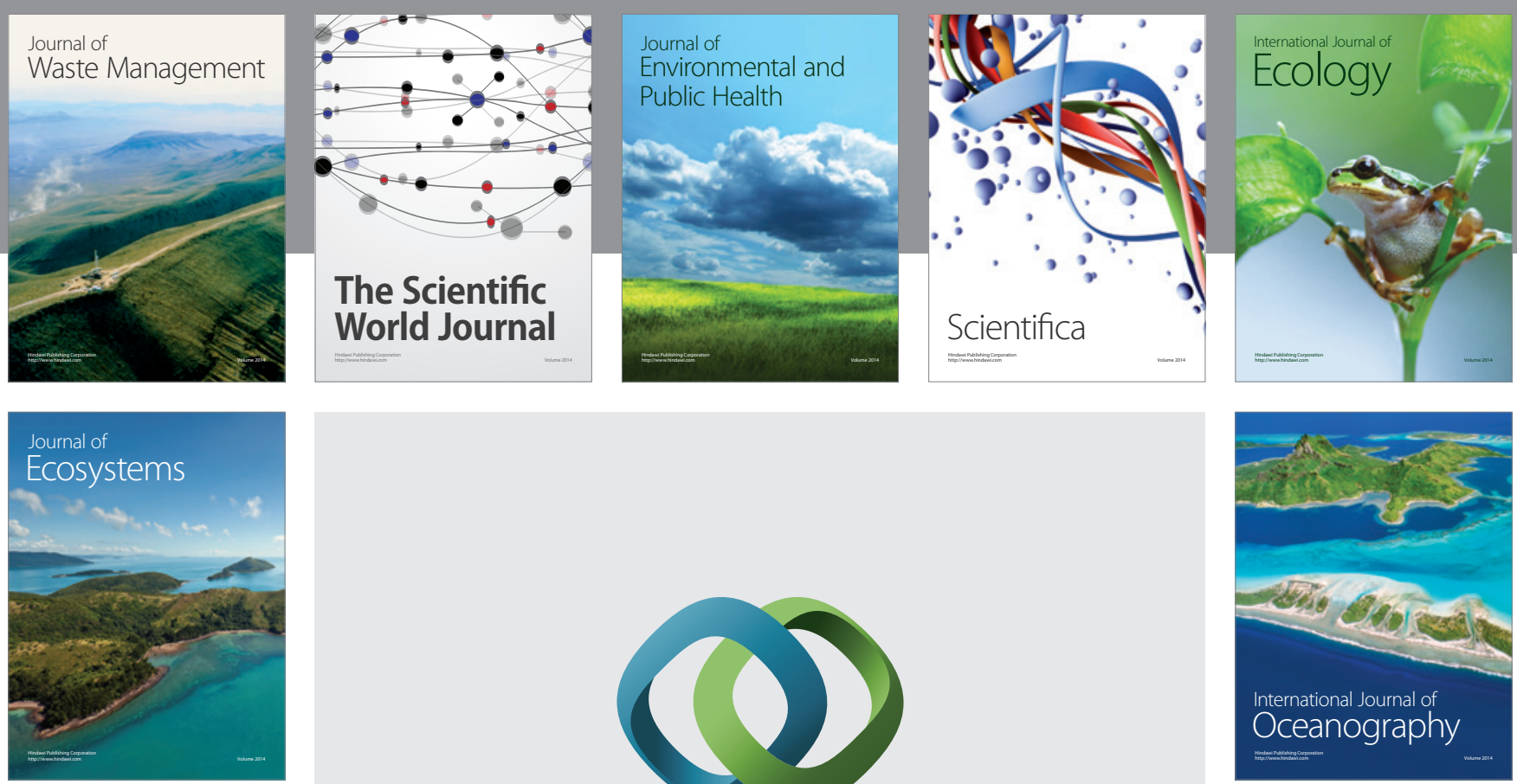

The Scientific World Journal
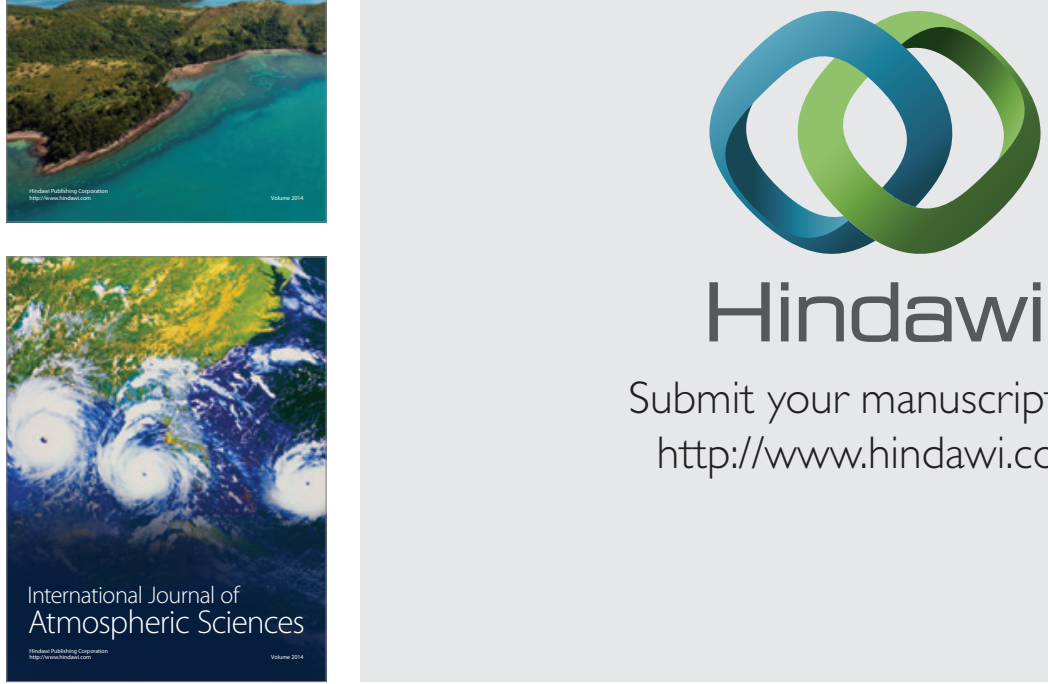

\section{Hindawi}

Submit your manuscripts at

http://www.hindawi.com
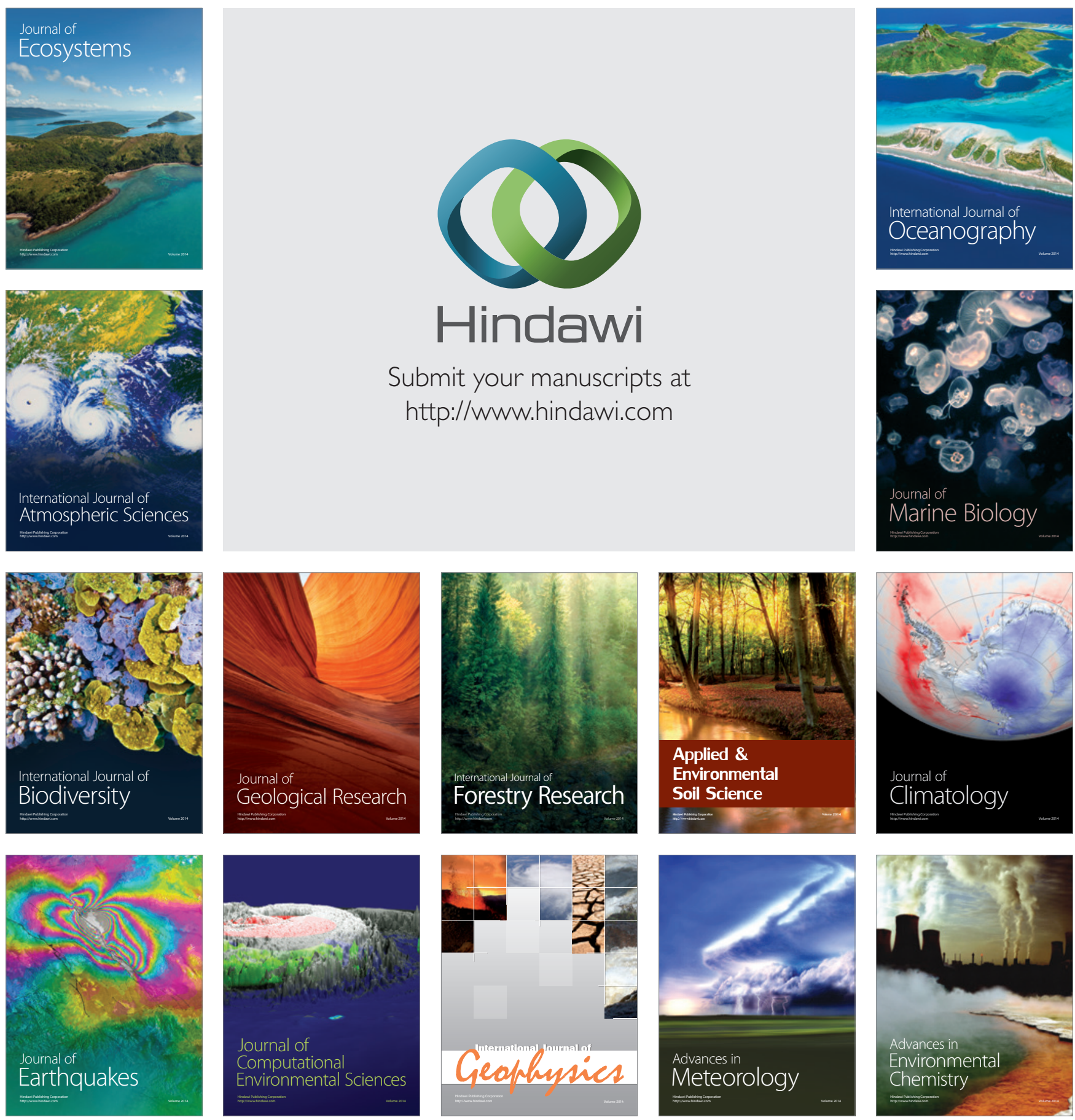